\title{
Pengaruh Current Ratio, Inventory Turnover dan Debt to Equity terhadap Return on Asset
}

\author{
Sindik Widati \\ Universitas Pelita Bangsa \\ sindikwidati@pelitabangsa.ac.id
}

\author{
Tania Dwi Hartini \\ Universitas Pelita Bangsa \\ Taniahartini38@gmail.com
}

\begin{abstract}
This study aims to determine the effect of Current Ratio, Inventory Turnover and Debt to Equity on Return on Asset Practice in Property and Real Estate companies listed on the Indonesia Stock Exchange period 2017-2019. The research method used in this study is a quantitative method. The data used are secondary data in the form of financial statements and annual reports. The sampling technique in this study was purposive sampling method in which sample selection was based on certain criteria. The study population used was 64, the research sample of 24 companies. The analysis technique in this study uses multiple linear regression analysis. The analysis shows that Current Ratio do not affect the Return on Asset, Inventory Turnover do not affect the Return on Asset and Debt to Equity do not affect the Return on Asset.
\end{abstract}

\section{Keywords C Current Ratio, Inventory Turnover, Debt to Equity, Return on Asset}

\section{PENDAHULUAN}

Tujuan perusahaan adalah memaksimisasi kesejahteraan atau kemakmuran pemegang saham. Tujuan perusahaan dapat dicapai dengan menyangkut aktivitas yang dilakukan untuk memperoleh (mendapatkan) dana dan menggunakan (mengalokasikan) dana tersebut. Apabila tujuan perusahaan sudah tercapai, maka perusahaan dapat menjalankan kegiatan operasi perusahaan nya dengan baik dan dapat berkembang serta memberikan pengembalian yang menguntungkan bagi pemiliknya, investor yang menanam modal kepada perusahaan mereka dan kreditur akan percaya bahwa uangnya yang dipinjamkan akan kembali. Semakin banyak investor yang menanam modal di perusahaan, maka nilai saham akan naik begitu juga dengan laba perusahaan.

Pada dasarnya motif didirikannya suatu perusahaan adalah untuk mendapatkan suatu laba yang maksimal, agar perusahaan bisa tetap going concern. Dalam mengukur laba yang dihasilkan suatu perusahaan serta kinerja perusahaan dapat dilihat dari rasio profitabilitasnya hal tersebut tercermin didalam teori laporan keuangan. Hal ini menegaskan bahwasannya bagi para investor dan kreditor dalam menginvestasikan hartanya haruslah melihat kemampuan perusahaan dan kinerja perusahaan yang dapat dilihat dari rasio profitabilitas. Return on Asset adalah metode yang digunakan dan diyakini perusahaan untuk melihat kemampulabaan perusahaan dan kinerja perusahaan. Namun, bagi investor dan kreditor melihat laba suatu perusahaan dengan sudut pandang yang berbeda. Hal yang menentukan naik atau turunnya nilai saham dipasar efek dimata para investor adalah berdasarkan besarnya laba dan juga aktivitas 
arus kas pendanaan tersebut. Sedangkan, bagi para kreditor yang menentukan lancar dan tidak lancarnya suatu pengembalian pinjaman adalah berdasarkan besarnya laba dan aktivitas arus kas operasi yang dimiliki suatu perusahaan tersebut. Untuk menilai kinerja suatu perusahaan itu baik atau tidaknya perlu itu perlu dilakukan analisis terhadap laporan keuangan dari perusahaan tersebut. Laporan keuangan merupakan sarana yang penting bagi investor untuk mengetahui perkembangan perusahaan secara periodik (Samsul, 2006), yang nantinya dapat menjadi dasar untuk mengambil suatu keputusan.

Laba usaha merupakan hasil atau keuntungan yang diperoleh dari aktivitas perusahaan. Tingkat efektivitas manajemen atas melakukan aktivitas operasional dapat diukur dengan menggunakan rasio aktivitas (Sari, 2016). Rasio ini juga disebut rasio perputaran secara umum semakin tinggi perputaran berarti semakin efektif tingkat penggunaan aset perusahaan. Rasio ini terutama mengamati aset-aset yang dianggap penting bagi perusahaan. Beberapa rasio aktivitas yang dapat digunakan adalah Account Receivable Turnover, Inventory Turnover, dan Total Asset Turnover.

Profitabilitas (laba) merupakan tujuan berdirinya sebuah perusahaan. Oleh sebab itu, perusahaan harus dapat menjaga tingkat laba yang dihasilkannya. Salah satu cara untuk mengukur profitabilitas adalah dengan menggunakan rasio return on asset. Return on asset merupakan rasio yang menunjukkan tingkat keuntungan yang diperoleh berdasarkan aktiva yang dimiliki perusahaan.

Current ratio diukur dengan menggunakan asset lancar. Jika jumlah asset lancar yang dimiliki perusahaan banyak, terutama kas. Hal ini menunjukkan bahwa perusahaan kurang maksimal menggunakan sumber daya yang dimiliki sehingga kegiatan operasional perusahaan menurun, diikuti dengan penurunan laba. Salah satu rasio solvabilitas adalah Debt To Equity Ratio (DER), rasio ini mengukur jumlah persentase dari jumlah dana yang diberikan oleh kreditur berupa utang terhadap modal sendiri (Hendra, 2017).

Perusahaan dapat dikatakan likuid apabila perusahaan tersebut tidak dapat memenuhi kewajiban jangka pendek. Kewajiban jangka pendek dikenal dengan istilah Likuiditas. Likuiditas adalah kemampuan perusahaan untuk membayar semua kewajiban jangka pendek pada saat jatuh tempo dengan menggunakan aset lancar yang tersedia di perusahaan. Sehingga perusahaan harus mengelola aset lancar dengan baik agar dapat melunasi kewajiban jangka pendek pada saat jatuh tempo. Penelitian ini penulis menggunakan perhitungan Current Ratio untuk menghitung likuiditas sebagai variabel independen . Semakin besar perbandingan aset lancar dan liabilitas lancar semakin tinggi kemampuan perusahaan menutupi kewajiban jangka pendeknya.

\section{LANDASAN TEORI}

\section{Current Ratio}

Menurut Van Horne (2021), rasio lancar adalah rasio yang mengukur kemampuan untuk memenuhi hutang jangka pendek dengan aset lancar. Sedangkan Kasmir (2014) menjelaskan current ratio digunakan untuk mengukur tingkat keamanan suatu perusahaan. Penghitungan current ratio dilakukan dengan membandingkan antara total aktiva dengan total hutang lancar. Current ratio atau rasio lancar merupakan rasio yang digunakan untuk mengukur kemampuan perusahaan dalam membayar kewajiban jangka pendeknya dengan menggunakan aktiva lancar yang dimiliki. Current ratio merupakan salah satu rasio likuiditas yang paling umum digunakan untuk mengukur kemampuan perusahaan dalam memenuhi kewajiban jangka pendek atau utang yang segera jatuh tempo pada saat ditagih secara keseluruhan. Dengan kata lain, rasio lancar ini menggambarkan seberapa besar jumlah ketersediaan aset lancar yang dimiliki perusahaan dibandingkan dengan total kewajiban 
lancar. Oleh sebab itu, rasio lancar dihitung sebagai hasil bagi antara total aset lancar dengan total kewajiban lancar.

\section{Inventory Turnover}

Rasio ini mengukur mengenai likuiditas dari persediaan. Rasio ini mengukur berapa kali rata-rata perputaran persediaan terjual selama setahun. Perputaran persediaan merupakan perbandingan antara harga pokok penjualan (cost of goods sold) dengan rata-rata persediaan. Indikatornya adalah semakin tinggi nilai perputaran persediaan semakin baik likuiditas persediaan tersebut. Ada dua masalah yang timbul dalam perhitungan dan analisis rasio perputaran persediaan. Pertama, penjualan dinilai menurut harga pasar (market price), persediaan dinilai menurut harga pokok penjualan (at cost), maka sebenarnya rasio yang dihitung dengan membagi penjualan dengan persediaan mengukur perputaran persediaan dalam kas. Namun banyak lembaga peneliti rasio keuangan yang menggunakan rasio perputaran persediaan (at market), sehingga bila ingin diperbandingkan dengan rasio industri, rasio perputaran persediaan (at market) ini sebaiknya digunakan. Kedua, penjualan terjadi sepanjang tahun sedangkan angka persediaan adalah gambaran keadaan sesaat. Oleh karena itu, lebih baik menggunakan rata-rata persediaan, yaitu persediaan awal ditambah persediaan akhir dibagi dua. Inventory turnover mengukur berapa lama rata-rata barang berada di gudang (Husna, 2016). Artinya semakin tinggi nilai inventory turnover yang diperoleh, semakin efisien perusahaan didalam melaksanakan operasinya. Dengan kata lain, perusahaan yang nilai perputaran persediaannya makin tinggi berarti makin efisien dalam kaitannya dengan pengendalian biaya, efisiensi dalam pengendalian biaya bagi perusahaan akan berdampak pada peningkatan perolehan laba (Saniman, 2007)

\section{Debt to Equity}

Deb to Equity Ratio mengukur besar kecilnya penggunaan utangdibanding modal sendiri (Sudana, 2011). Rasio utang terhadap modal merupakan rasio yang digunakan untuk mengukur besarnya proporsi utang terhadap modal. Rasio ini dihitung sebagai hasil bagi antara total utang dengan modal. Rasio ini berguna untuk mengetahui besarnya perbandingan antara jumlah dana yang disediakan oleh kreditor dengan jumlah dana yang berasal dari pemilik perusahaan. Dengan kata lain, rasio ini berfungsi untuk mengetahui berapa bagian dari setiap rupiah modal yang dijadikan sebagai jaminan utang. Rasio ini memberikan petunjuk umum tentang kelayakan kredit dan risiko keuangan debitor. Memberikan pinjaman kepada debitor yang memiliki tingkat yang tinggi menimbulkan konsekuensi bagi kreditor untuk menanggung risiko yang lebih besar pada saat debitor mengalami kegagalan keuangan. Hal ini tentu saja sangat tidak menguntungkan bagi kreditor. Sebaliknya, apabila kreditor memberikan pinjaman kepada debitor yang memiliki tingkat yang rendah (yang berarti tinggi nya tingkat pendanaan debitor yang berasal dari modal pemilik) maka hal ini dapat mengurangi risiko kreditor (dengan adanya batas pengaman yang besar) pada saat debitor mengalami kegagalan keuangan. Dengan kata lain, akan lebih aman bagi kreditor apabila memberikan pinjaman kepada debitor yang memiliki tingkat yang rendah karena hal ini berarti bahwa akan semakin besar jumlah modal pemilik yang dapat dijadikan sebagai jaminan utang.

\section{Return on Asset}

Hasil pengembalian atas aset merupakan rasio yang menunjukkan seberapa besar kontribusi aset dalam enciptakan laba bersih. Dengan kata lain, rasio ini digunakan untuk mengukur seberapa besar jumlah laba bersih yang akan dihasilkan dari setiap rupiah dana yang tertanam 
dalam total aset. Rasio ini dihitung dengan membagi laba bersih terhadap total aset. Semakin tinggi hasil pengembalian atas aset berarti semakin tinggi pula jumlah laba bersih yang dihasilkan dari setiap rupiah dana yang tertanam dalam total aset. Sebaliknya, semakin rendah hasil pengembalian atas aset berarti semakin rendah pula jumlah laba bersih yang dihasilkan dari setiap rupiah dana yang tertanam dalam total aset. Menurut Sujarweni (2017) Return on asset merupakan rasio yang digunakan untuk mengukur kemampuan dari modal yang diinvestasikan dalam keseluruhan aktiva untuk menghasilkan keuntungan net. Husna (2016) menyebutkan bahwa ROA menunjukkan seberapa banyak laba bersih yang bisa dipoles dari seluruh kekayaan yang dimiliki oleh perusahaan. ROA diukur dari laba bersih setelah pajak (Earning After Tax/Net Income After Tax) terhadap total asetnya yang mencerminkan kemampuan perusahaan dalam penggunaan investasi yang digunakan untuk operasi perusahaan dalam rangka menghasilkan profitabilitas perusahaan

\section{METODE PENELITIAN}

Desain penelitian adalah jenis penelitian kuantitatif dengan melakukan uji hipotesis. Data yang digunakan adalah data sekunder dengan melihat laporan tahunan perusahaan Property dan Real Estate yang terdaftar di Bursa Efek Indonesia periode 2017-2019. Data penelitian ini diperoleh dari Annual report perusahaan dengan cara mengakses di www.idx.co.id. Penelitian ini dilakukan dengan cara mengambil data laporan keuangan tahunan periode 2017-2019 perusahaan-perusahaan Property dan Real Estate yang terdaftar di Bursa Efek Indonesia melalui website resmi BEI di www.idx.co.id. Adapun populasi dalam penelitian ini adalah seluruh perusahaan Property dan Real Estate yang terdaftar di Bursa Efek Indonesia (BEI) selama periode 2017-2019.Teknik pengambilan sampel yang digunakan dalam penelitian ini adalah dengan menggunakan metode purposive sampling yaitu metode penentuan sampel dengan pertimbangan tertentu. Dengan menggunakan karakteristik sebagai berikut :

a. Perusahaan Property dan Real Estate yang terdaftar di Bursa Efek Indonesia tahun 20172019.

b. Perusahaan Property dan Real Estate yang menerbitkan laporan keuangan pada Bursa Efek Indonesia yang telah di publikasikan pada tahun 2017-2019 secara berturut turut.

c. Ketersediaan dan kelengkapan data selama penelitian. Apabila dalam proses penelitian terdapat perusahaan yang tidak dapat dihitung rasionya, maka akan dikeluarkan.

d. Perusahaan Property dan Real Estate yang menggunakan mata uang rupiah (IDR) dalam penyusunan laporan keuangan.

\section{HASIL DAN PEMBAHASAN}

\section{Uji Statistik Deskriptif}

Analisis deskriptif digunakan untuk memberikan gambaran suatu data yang dilihat dari nilai rata-rata (mean), nilai minimum, nilai maksimum, dan standar deviasi dari masing-masing variabel serta jumlah data $(\mathrm{N})$ yang digunakan dalam penelitian ini.

Tabel 1 Hasil Output Uji Statistik Deskriptif

Descriptive Statistics

\begin{tabular}{lccccc}
\hline & & \multicolumn{2}{c}{ Minimu } & Maximu & \multicolumn{2}{c}{ Std. } \\
& $\mathrm{N}$ & $\mathrm{m}$ & $\mathrm{m}$ & Mean & Deviation \\
\hline CR & 72 &, 011 & 9,666 & $\begin{array}{r}1,3471 \\
7\end{array}$ & 1,462550 \\
& & & & 1,5823 & \\
IT & 72 &, 002 & 32,317 & 9 & 4,804410
\end{tabular}




\begin{tabular}{lrrrrr} 
DER & 72 &, 032 & 3,094 &, 83886 &, 721654 \\
ROA & 72 &, 000 &, 064 &, 02421 &, 017381 \\
Valid N & 72 & & & & \\
(listwise) & 72 & & & & \\
\hline
\end{tabular}

Sumber: Output SPSS versi 22, 2020

\section{Hasil Uji Kolmogorof Smirnov}

Hasil uji Kolmogorov Smirnov menunjukkan hasil bahwa data terdistribusi normal. Hal ini dapat dilihat dari Asymp Sig (2-tailed) atau probabilitasnya yang menunjukkan angka 0,054 lebih besar dari tingkat signifikansi 0,05. Maka dapat disimpulkan bahwa distribusi data adalah normal.

\section{Tabel 2. Hasil Uji Kolmogorov-Smirnov}

One-Sample Kolmogorov-Smirnov Test

\begin{tabular}{llr}
\hline & & $\begin{array}{c}\text { Unstandardized } \\
\text { Residual }\end{array}$ \\
\hline $\mathrm{N}$ Normal Parameters & & 72 \\
& Mean & .0000000 \\
Most Extreme Differences & Std. Deviation & 16.95206689 \\
& Absolute & .103 \\
& Positive & .103 \\
Test Statistic & Negative & -.064 \\
Asymp. Sig. (2-tailed) & & .103 \\
\hline
\end{tabular}

\section{Uji}

\section{Multikoinearitas}

Uji multikolinearitas bertujuan untuk menguji apakah model regresi ditemukan adanya korelasi antar variabel bebas (independen). Deteksi multikolinearitas pada suatu model dapat dilihat dimana nilai Variance Inflation Factor (VIF) tidak lebih dari 10 dan nilai Tolerance tidak kurang dari 0,1. Maka model tersebut dikatakan terbebas dari multikolinearitas. Berikut ini adalah hasil Uji Multikolinearitas

\section{Tabel 3 Hasil Uji Multikolinearitas} Coefficients ${ }^{\mathrm{a}}$

\begin{tabular}{|c|c|c|c|c|c|c|c|}
\hline \multirow[b]{2}{*}{ Model } & \multicolumn{2}{|c|}{$\begin{array}{l}\text { Unstandardized } \\
\text { Coefficients }\end{array}$} & \multirow{2}{*}{$\begin{array}{l}\text { Standardized } \\
\text { Coefficients }\end{array}$} & \multirow[b]{2}{*}{$\mathrm{t}$} & \multirow[b]{2}{*}{ Sig. } & \multicolumn{2}{|c|}{$\begin{array}{l}\text { Collinearity } \\
\text { Statistics }\end{array}$} \\
\hline & B & Std. Error & & & & Tolerance & VIF \\
\hline 1 (Constant) & 21.908 & 4.374 & & 5.008 & .000 & & \\
\hline CR & -.001 & .002 & -.051 & -.402 & .689 & .853 & 1.173 \\
\hline IT & .000 & .000 & -.105 & -.873 & .386 & .975 & 1.025 \\
\hline DER & .004 & .003 & .184 & 1.422 & .159 & .833 & 1.200 \\
\hline
\end{tabular}

a. Dependent Variable: ROA

Sumber : Output SPSS versi 22, 2020 
Berdasarkan tabel tersebut dapat dilihat hasil yang diperoleh dari nilai tolerance dan VIF. Nilai tolerance untuk Variabel Current Ratio (X1) sebesar 0,853 dengan nilai VIF sebesar 1,173. Untuk Variabel Inventory Turnover (X2) mempunyai nilai tolerance sebesar 0,975 dan nilai VIF sebesar 1,025. Untuk Variabel Debt to Equity (X3) nilai tolerance menunjukkan angka 0,833 dan nilai VIF sebesar 1,200. Masing-masing variabel independen tersebut memiliki angka tolerance diatas 0,1 dan VIF $<10$, jadi dapat disimpulkan bahwa tidak terdapat gejala multikolinearitas antar variabel independen ini.

\section{Uji Autokorelasi}

Uji ini dilakukan untuk menguji apakah model regresi linear ada korelasi antara kesalahan pengganggu pada tahun periode $t$ dengan kesalahan pengganggu pada periode $t-1$ (sebelumnya). Terbebasnya suatu model dari autokorelasi dapat dilihat dari angka Durbin Watson Test. Hasil pengujian autokorelasi dapat dilihat pada tabel berikut :

Tabel 4. Uji Autokorelasi Durbin-Watson Model Summary ${ }^{\text {b }}$

\begin{tabular}{|c|c|c|c|c|c|}
\hline Model & $\mathrm{R}$ & R Square & $\begin{array}{l}\text { Adjusted R } \\
\text { Square }\end{array}$ & $\begin{array}{l}\text { Std. Error of the } \\
\text { Estimate }\end{array}$ & Durbin-Watson \\
\hline 1 & $.221^{\mathrm{a}}$ & .049 & .007 & 17.322 & 1.038 \\
\hline
\end{tabular}

Sumber: Output SPSS versi 22, 2020

Dengan melihat tabel model summary diatas, angka Durbin Watson menunjukkan 1,038. Nilai ini akan dibandingkan dengan nilai tabel signifikansi 5\%. Jumlah sampel (n) sebanyak 72 dan jumlah variabel independen $3(\mathrm{k}=3)$, maka pada tabel DW akan didapatkan nilai $\mathrm{dL}=$ 1,5323 dan $\mathrm{dU}=1,7054$. Nilai $\mathrm{DW}$ adalah 1,038 dan berada di antara dU dan 4-dU. Artinya 1,038 lebih kecil dari dL $(1,5323)$ dan kurang dari 4-dU $(2,2946)$, maka dapat disimpulkan bahwa terdapat masalah autokorelasi pada model, sehingga model regresi tidak layak dipakai untuk analisis selanjutnya.

Untuk meningkatkan uji Autokorelasi, maka selain dilakukan pengujian dengan Durbin Watson, maka perlu dilakukan pengujian secara statistik, yaitu dengan menggunakan uji Run Test. Hasil pengujian Run Test dapat dilihat pada tabel berikut:

Tabel 5. Hasil Uji Run Test

\begin{tabular}{|l|r|}
\hline \multicolumn{2}{|c|}{ Runs Test } \\
\hline & \multicolumn{1}{|c|}{ Unstandardized Residual } \\
\hline Test Value $^{\mathrm{a}}$ & .31709 \\
\hline Cases $<$ Test Value & 35 \\
\hline Cases >= Test Value & 36 \\
\hline Total Cases & 71 \\
\hline Number of Runs & 30 \\
\hline Z & -1.553 \\
\hline Asymp. Sig. (2-tailed) & .121 \\
\hline
\end{tabular}

Sumber : Output SPSS versi 22, 2020 
Berdasarkan tabel tersebut diketahui nilai Asymp Sig (2-tailed) sebesar 0,121>dari 0,05. Dengan demikian, masalah autokorelasi yang tidak dapat terselesaikan dengan Durbin-Watson dapat teratasi melalui uji Run Test sehingga analisis Regresi linear dapat dilanjutkan.

\section{Uji Heteroskedastisitas}

Uji ini digunakan untuk menguji apakah dalam sebuah model regresi terjadi ketidaksamaan varian dari residual suatu pengamatan ke pengamatan lainnya. Model yang baik adalah yang tidak terjadi heteroskedastisitas. Untuk mendeteksi adanya gejala heteroskedastisitas digunakan uji Glejser. Apabila nilai sig > 0,05, maka data tersebut bebas dari heteroskedastisitas. Pengujian heteroskedastisitas adalah sebagai berikut :

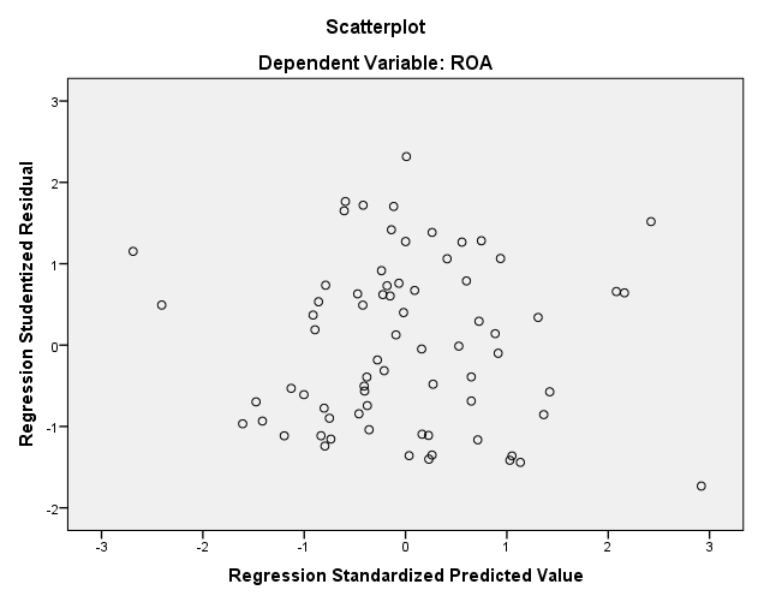

Gambar 1. Hasil Uji Heteroskedastisitas

Sumber : Output SPSS versi 22, 2020

\section{Hasil Uji Koefisien Determinasi (Adjusted R²)}

Pengujian regresi linear berganda ini dianalisis pula besarnya koefisien determinasi dalam penelitian ini digunakan untuk melihat besarnya pengaruh variabel independen (Current Ratio, Inventory Turnover dan Debt to Equity) terhadap variabel dependen (Return on Asset). Hasil pengujian menunjukkan nilai $\mathrm{R}^{2}$ seperti terlihat pada tabel 4.7 disebabkan oleh variabel lain yang tidak diteliti dalam penelitian ini.

Tabel 6. Hasil Uji Koefisien Determinasi (Adjusted R²) Model Summary

\begin{tabular}{rrrrr}
\hline Model & $\mathrm{R}$ & $\mathrm{R}$ Square & Adjusted R Square & Std. Error of the Estimate \\
\hline 1 &, $313^{\mathrm{a}}$ &, 098 &, 057 & 1,06382 \\
\hline
\end{tabular}

Sumber : Output SPSS versi 22, 2020

Berdasarkan tabel diatas, dapat dilihat bahwa nilai adjusted $\mathrm{R}^{2}$ diperoleh sebesar 0,057 . Hal ini berarti Current Ratio (X1), Inventory Turnover (X2) dan Debt to Equity (X3) berpengaruh terhadap Return on Asset (Y) sebesar 5,7\%. Sedangkan sisanya yaitu sebesar $(100 \%-5,7 \%)=$ 94,3\% dijelaskan oleh faktor - faktor lain selain variabel yang diteliti di atas.

\section{Uji Parsial (t)}

Uji hipotesis dilakukan untuk mengetahui ada tidaknya pengaruh yang signifikan antara variabel bebas : Current Ratio (X1), Inventory Turnover (X2) dan Debt to Equity (X3) terhadap Return on Asset (Y). Pengujian ini dilakukan dengan menggunakan besarnya nilai Retun On 
Asset (p-value) masing-masing koefisien regresi variabel independen dibandingkan dengan tingkat signifikansi $(\alpha)$. Berikut hasil uji t disajikan dalam tabel berikut :

Tabel 7. Hasil Uji t

\begin{tabular}{|c|c|c|c|c|c|c|}
\hline \multicolumn{7}{|c|}{ Coefficients $^{a}$} \\
\hline & & \multicolumn{2}{|c|}{$\begin{array}{c}\text { Unstandardized } \\
\text { Coefficients }\end{array}$} & \multirow{2}{*}{$\begin{array}{c}\text { Standardized } \\
\text { Coefficients }\end{array}$} & \multirow[b]{2}{*}{$\mathrm{T}$} & \multirow[b]{2}{*}{ Sig. } \\
\hline \multicolumn{2}{|c|}{ Model } & B & Std. Error & & & \\
\hline \multirow[t]{4}{*}{1} & (Constant) & 21,908 & 4,374 & & 5,008 & ,000 \\
\hline & $\mathrm{CR}$ &,- 001 & ,002 &,- 051 &,- 402 & 689 \\
\hline & IT & ,000 & ,000 &,- 105 &,- 873 & ,386 \\
\hline & DER & ,004 & ,003 & , 184 & 1,422 & , 159 \\
\hline
\end{tabular}

Berdasarkan hasil pengujian pada tabel tersebut dapat disimpulkan bahwa :

1. Variabel Current Ratio (X1) secara statistik menunjukkan hasil yang tidak signifikan. Hal ini dapat dilihat dari nilai signifikansi 0,689 lebih besar dari 0,05 (5\%). Dengan demikian, hipotesis ke satu (H1) yang menyatakan bahwa Current Ratio tidak berpengaruh terhadap terhadap Return on Asset.

2. Variabel Inventory Turnover (X2) secara statistik menunjukkan hasil yang tidak signifikan 0,386 lebih besar dari 0,05 (5\%). Dengan demikian hipotesis kedua $(\mathrm{H} 2)$ yang menyatakan bahwa Inventory Turnover tidak berpengaruh terhadap Return on Asset.

3. Variabel Debt to Equity (X3) secara statistik menunjukkan hasil yang tidak signifikan. Hal ini dapat dilihat dari signifikansi 0,159 lebih besar dari 0,05 (5\%). Dengan demikian hipotesis ketiga (H3) yang menyatakan bahwa Debt to Equity tidak berpengaruh terhadap Return on Asset.

\section{Uji Simultan (F)}

Uji statistik F pada dasarnya menunjukkan apakah semua variabel independen yang dimasukkan dalam model mempunyai pengaruh secara bersama-sama / simultan terhadap variabel dependen (Imam Ghozali, 2009:16). Berikut hasil uji F yang diolah menggunakan SPSS disajikan dalam tabel berikut :

Tabel 8. Hasil Uji F ANOVA

\begin{tabular}{lrrrrr}
\hline Model & Sum of Squares & Df & Mean Square & F & Sig. \\
\hline 1 Regression & 1044,422 & 3 & 348,141 & 1,160 &, $331^{\mathrm{b}}$ \\
Residual & 20403,453 & 68 & 300,051 & & \\
Total & 21447,875 & 71 & & & \\
\hline
\end{tabular}

Sumber: Output SPSS versi 22, 2020

Berdasarkan uji pada tabel diatas, diketahui nilai Fhitung sebesar 1,160. Karena nilai Fhitung lebih kecil dari Ftabel. Dengan nilai signifikansi 0,331 lebih besar dari nilai 0,05 sehingga dapat disimpulkan bahwa tidak terdapat pengaruh secara simultan atau bersama-sama antara variabel independen yang meliputi Current Ratio, Inventory Turnover dan Debt to Equity terhadap variabel dependen yaitu Return on Asset. 


\section{Hasil Uji Analisis Regresi Linear Berganda}

Analisis regresi linear berganda merupakan analisis yang digunakan untuk mengetahui pengaruh Current ratio, Inventory turnover dan Debt to Equity terhadap Return on Asset. Berdasarkan data dapat dilihat pada tabel 4.10 persamaan regresi linear berganda dengan pengukuran return on asset yang diperoleh berdasarkan hasil perhitungan statistik seperti terlihat pada tabel berikut :

\section{Tabel 9. Hasil Uji Regresi Linear Berganda}

Coefficients $^{\mathbf{a}}$

\begin{tabular}{lrrrrrr}
\hline & \multicolumn{2}{c}{ Unstandardized Coefficients } & \multicolumn{2}{c}{ Standardized Coefficients } & & \\
\cline { 2 - 6 } Model & \multicolumn{1}{c}{ B } & Std. Error & Beta & T & Sig. \\
\hline 1 (Constant) & 21.908 & 4.374 & & 5.008 & .000 \\
CR & -.001 & .002 & -.051 & -.402 & .689 \\
IT & .000 & .000 & -.105 & -.873 & .386 \\
DER & .004 & .003 & .184 & 1.422 & .159 \\
\hline
\end{tabular}

Sumber: Output SPSS versi 22, 2020

Dari tabel diatas dapat disusun model persamaan regresi linear berganda berdasarkan kolom B. Model persamaan regresi linear berganda hasil penelitian adalah sebagai berikut :

$$
\mathrm{Y}=21,908+-0,001 \mathrm{X}^{1}+0,000 \mathrm{X}^{2}+0,004 \mathrm{X}^{3}+4,374
$$

Model persamaan regresi linear berganda hasil analisis tersebut dapat diartikan sebagai berikut

1. Nilai konstanta sebesar 21,908 artinya apabila nilai variabel current ratio, inventory turnover dan debt to equity bernilai 0, maka Return on asset bernilai sebesar 21,908 atau berkurang sebesar $219 \%$.

2. Jika nilai current ratio meningkat $100 \%$ atau satu satuan maka nilai return on asset akan meningkat sebesar $-0,001$ atau $-0,1 \%$

3. Jika nilai inventory turnover meningkat $100 \%$ atau satu satuan maka nilai return on asset akan meningkat sebesar 0,000 .

4. Jika nilai debt to equity meningkat $100 \%$ atau satu satuan maka nilai return on asset akan menurun sebesar 0,004 atau $0,04 \%$.

\section{Hasil Pembahasan}

\section{Pengaruh Current Ratio terhadap Return on Asset}

Hipotesis pertama menyatakan bahwa Current Ratio tidak berpengaruh terhadap Return on Asset. Hasil pengujian untuk variabel Current Ratio bahwa nilai koefisien regresi sebesar 0,001 dengan signifikansi lebih besar 0,05 (0,689 > 0,05), sehingga dapat disimpulkan bahwa Current Ratio tidak berpengaruh terhadap Return on Asset pada perusahaan property dan real estate yang terdaftar di Bursa Efek Indonesia tahun 2017-2019, maka Hipotesis 1 diterima. Hal ini menunjukkan bahwa semakin tinggi tinggi nilai Current Ratio maka profitabilitas yang dihasilkan perusahaan semakin rendah karena rasio lancar yang tinggi menunjukkan adanya kelebihan aktiva lancar yang tidak baik terhadap profitabilitas perusahaan. Hal ini sesuai dengan penelitian yang telah dilakukan oleh Saragih et al (2015) bahwa Current Ratio berpengaruh negatif dan signifikan terhadap Return on Asset.

\section{Pengaruh Inventory turnover terhadap Return on Asset}

Dari hasil perhitungan diatas, variabel Inventory turnover memiliki nilai signifikan sebesar 0,386 lebih besar dari taraf signifikan 0,05 sehingga dapat disimpulkan bahwa variabel Inventory turnover tidak berpengaruh secara parsial terhadap Return on Asset. Hal ini 
mengindikasikan bahwa perubahan yang terjadi pada rasio Inventory turnover perusahaan tidak berpengaruh signifikan terhadap tindakan Return on Asset. Nilai koefisien yang dimiliki sebesar 0,000 menunjukkan Inventory turnover berhubungan positif terhadap Return on Asset. Adanya pengaruh yang signifikan diduga disebabkan oleh adanya investasi yang besar dalam persediaan yang sesuai dengan kebutuhan, sehingga akan meperbesar biaya penyimpanan dan pemeliharaan di gudang, serta memperbesar kemungkinan keuntungan. Hal ini menggambarkan bahwa $\mathrm{H} 2$ yang menyatakan Inventory turnover berpengaruh negatif terhadap return on asset diterima. Hal ini bertolak belakang dengan hasil penelitian yang dilakukan oleh Widiyanti (2014), yang menyatakan bahwa Inventory Turnover secara parsial berpengaruh positif dan signifikan terhadap Return on Asset.

\section{Debt to Equity berpengaruh positif terhadap Return on Asset}

Dari hasil perhitungan diatas, variabel Debt to Equity memiliki nilai signifikan sebesar 0,159 lebih besar dari taraf signifikan 0,05 sehingga dapat disimpulkan bahwa variabel Debt to Equity tidak berpengaruh secara parsial terhadap return on asset. Hal ini mengindikasikan bahwa perubahan yang terjadi pada Debt to Equity perusahaan tidak berpengaruh signifikan terhadap tindakan return on asset. Nilai koefisien yang dimiliki sebesar 0,004 menunjukkan pertumbuhan penjualan berhubungan positif terhadap return on asset. Hal ini menggambarkan bahwa H3 yang menyatakan Debt to equity berpengaruh positif terhadap return on asset diterima. Hal ini bertolak belakang dengan penelitian yang telah dilakukan oleh Thoyib et al (2018), yang menyatakan bahwa Debt to Equity secara parsial berpengaruh positif dan signifikan terhadap Return on Asset.

\section{Pengaruh Current Ratio, Inventory Turnover dan Debt to Equity terhadap Return on Asset}

Dari hasil perhitungan secara simultan diperoleh nilai signifikansi dari Current ratio, Inventory turnover dan Debt to Equity sebesar 0,000. Karena nilai signifikansi variabel independen lebih kecil dari 0,05, maka dapat disimpulkan bahwa secara simultan Current ratio, Inventory turnover dan Debt to Equity yang tejadi dapat berpengaruh terhadap Return on asset. Nilai Fhitung yang dimiliki sebesar 1,160 menunjukan bahwa Current ratio, Inventory turnover dan Debt to Equity berhubungan positif terhadap Return on Asset. Pengaruh positif yang ditunjukan oleh Current ratio, Inventory turnover dan Debt to Equity mengindikasikan bahwa apabila Current ratio, Inventory turnover dan Debt to Equity kecil, maka tindakan Return on Asset juga akan kecil dan sebaliknya. Semakin besar Current ratio, Inventory turnover dan Debt to Equity, maka mengindikasikan tindakan Return on Asset juga cenderung besar. Hal ini menggambarkan bahwa $\mathrm{H} 4$ yang menyatakan Current ratio, Inventory turnover dan Debt to Equity berpengaruh terhadap Return on Asset yang diajukan diterima. Hasil penelitian terdahulu mengenai Current Ratio, Debt to Equity dan Inventory Turnover secara simultan berpengaruh positif dan signifikan terhadap Return on Asset yang dilakukan oleh Supardi et al (2018).

\section{V. KESIMPULAN}

Penelitian ini bertujuan untuk mengetahui pengaruh Current ratio, Inventory turnover dan Debt to Equity terhadap Return on Asset pada perusahaan Property dan Real Estate periode 2017-2019. Berdasarkan pada data yang telah dikumpulkan dan pengujian yang dilakukan telah dilakukan dengan menggunakan model regresi berganda, maka dapat diambil kesimpulan bahwa Current ratio tidak berpengaruh signifikan terhadap return on asset, hal ini dilihat dari 
nilai $\mathrm{t}$ tabel yang lebih besar dari 0,05 dengan nilai signifikansi 0,689 dengan nilai koefisien sebesar -0,001. Inventory turnover tidak berpengaruh signifikan terhadap return on asset, hal ini dilihat dari t tabel yang lebih besar dari 0,05 dengan nilai signifikansi 0,386 dengan nilai koefisien sebesar 0,000. Debt to equity tidak berpengaruh signifikan terhadap return on asset, hal ini dapat dilihat dari nilai t tabel yang lebih besar dari 0,05 yaitu sebesar 0,159 dengan nilai koefisien 0,004. Current ratio, Inventory turnover dan Debt to equity secara simultan berpengaruh terhadap Return on asset, hal ini dilihat dari nilai $\mathrm{F}=1,160$ dengan nilai signifikan 0,331 . Hasil perhitungan nilai koefisien determinasi (Adjusted $\mathrm{R}^{2}$ ) adalah sebesar 0,057 . Hal ini berarti varians Current ratio, Inventory turnover dan Debt to equity secara simultan berpengaruh terhadap Return on asset sebesar 5,7 \%. Ini menunjukkan bahwa masih banyak variabel independen di luar fungsi yang dapat mempengaruhi Beta yaitu sebesar 0,943 atau $94,3 \%$.

\section{DAFTAR PUSTAKA}

Hendra, H. (2017). PENGARUH PROFITABILITAS, PERTUMBUHAN PERUSAHAAN, DAN KEBIJAKAN HUTANG SEBAGAI DETERMINAN KEBIJAKAN DIVIDEN (STUDI PADA PERUSAHAAN MANUFAKTUR DI BEI PERIODE 2009-2011). Jurnal Akuntansi Bisnis, 6(1).

Husna, N. (2016). Analisis Firm Size, Growth Opportunity Dan Total Asset Turn Over Terhadap Return On Asset Kasus Pada Perusahaan Food Beverages. Jurnal Apresiasi Ekonomi, 4(1), 65-70.

Kasmir. (2014). Analisis Laporan Keuangan (satu. Ceta). PT Raja Grafindo Persada.

Samsul, M. (2006). Pasar modal dan manajemen portofolio.

Saniman, W. (2007). Analis Pengaruh Rasio Aktivitas, Rasio Profitabilitas dan Rasio Pasar terhadap Return saham Syariah dalam Kelompok Jakarta Islamic Index (JII) tahun 20032005. Tesis.

Saragih, M., Siahaan, Y., Purba, R., \& Supitriyani, S. (2015). Pengaruh current ratio terhadap return on asset pada perusahaan sektor aneka industri yang listing di bursa efek Indonesia. Financial: Jurnal Akuntansi, 1(1), 19-24.

Sari, N. (2016). Pengaruh rasio keuangan terhadap harga saham pada perusahaan manufaktur yang terdaftar di Bursa Efek Indonesia tahun 2010-2014. Jurnal Adminika, 2(2).

Sudana, I. M. (2011). Manajemen keuangan perusahaan teori dan praktik. Jakarta: Erlangga. Sujarweni, V. W. (2017). Analisis Laporan Keuangan; Teori, Aplikasi, dan Hasil Penelitian. Supardi, H., Suratno, H. S. H., \& Suyanto, S. (2018). Pengaruh Current Ratio, Debt to Asset Ratio, Total Asset Turnover dan Inflasi Terhadap Return on Asset. JIAFE (Jurnal Ilmiah Akuntansi Fakultas Ekonomi), 2(2), 16-27.

Thoyib, M., Firman, F., Amri, D., Wahyudi, R., \& Melin, M. A. (2018). Pengaruh Current Ratio, Debt To Asset Ratio, Debt To Equity Ratio Dan Total Asset Turnover Terhadap Return On Assets Pada Perusahaan Roperti Dan Real Estate Di Bursa Efek Indonesia. Akuntanika, 4(2), 10-23.

Van Horne, J. C., \& Wachowicz, J. M. (2021). Prinsip-prinsip manajemen keuangan.

Widiyanti, M., \& Bakar, S. W. (2014). Pengaruh working capital turnover, cash turnover, inventory turnover dan current ratio terhadap profitabilitas (roa) perusahaan property dan real estate yang terdaftar di bei. Jurnal Manajemen Dan Bisnis Sriwijaya, 12(2), 111-126. 